®B. І. Похилько, О. О. Калюжка, О. Б. Козакевич

\author{
ВДНЗУ «Украӥнська медична стоматологічна академія»
}

\title{
ВПЛИВ ПОЛІМОРФІЗМУ ГЕНІВ СІМЕЙСТВА ГЛУТАТІОН^^ТРАНСФЕРАЗ НА РОЗВИТОК ТА ЗАХВОРЮВАНІСТЬ ПЕРЕДЧАСНО НАРОДЖЕНИХ ДІТЕЙ 3 БРОНХОЛЕГЕНЕВОЮ ДИСПЛАЗІЕЮ
}

\begin{abstract}
ВПЛИВ ПОЛІМОРФІЗМУ ГЕНІВ СІМЕЙСТВА ГЛУТАТІОН-З-ТРАНСФЕРАЗ НА РОЗВИТОК ТА ЗАХВОРЮВАНІСТЬ ПЕРЕДЧАСНО НАРОДЖЕНИХ ДІТЕЙ 3 БРОНХОЛЕГЕНЕВОЮ ДИСПЛАЗІЮ. МеТоЮ роботИ буЛО вИвЧИтИ захворюваністЬ та розвиток передчасно народжених дітей з бронхолегеневою дисплазією (БЛД) упродовж перших двох років життя та ідентифікувати фактори ризику, включаючи поліморфізм G3T генів, які достовірно асоціюються з розвитком негативних наслідків при БЛД. Проведено когортне проспективне дослідження, в яке включено 33 дитини з БЛД, виписані з лікувальних закладів Полтавської області упродовж 2010-2013 рр. Вивчено їх психоемоційний, статокінетичний розвиток у 6, 12, 18 та 24 місяці життя. Оцінено частоту гострих респіраторних вірусних інфекцій, бронхіту та пневмонії' в ті ж самі вікові періоди. Досліджено частоту виявлення поліморфізму GSTT1, GSTM1 та GSTP1 генів. Для вивчення зв'язку між визначеними незалежними змінними та клініко-генетичними фракторами проведено логістичний регресійний аналіз. Делеційний поліморфізм генів сімейства глутатіон-3-трансфераз не пов'язаний зі статокінетичним та психоемоційним розвитком дітей з БЛД, а також з підвищеною частотою у них гострих інфекційних захворювань органів дихання упродовж перших двох років життя. Психоемоційний розвиток дітей з БЛД достовірно асоціюється з тривалістю ШВЛ (ВШ 1,269; $95 \%$ ДІ 1,01-1,603, p=0,045) та не асоціюється з іншими факторами (маса при народженні, гестаційний вік, забезпечення калоріями і білком на 28 добу життя, чоловіча стать). Не виявлено достовірного впливу генетичних факторів на розвиток передчасно народжених дітей з БЛД та частоту гострих інфекційних захворювань органів дихання. Потрібні подальші дослідження на більшій кількості пацієнтів для пошуку клініко-генетичних фракторів, які впливають на негативні віддалені наслідки у дітей з БлД.
\end{abstract}

ВЛИЯНИЕ ПОЛИМОРФИЗМА ГЕНОВ СЕМЕЙСТВА ГЛУТАТИОН-З-ТРАНСФЕРАЗ НА РАЗВИТИЕ И ЗАБОЛЕВАЕМОСТЬ НЕДОНОШЕННЫХ ДЕТЕЙ С БРОНХОЛЕГОЧНОЙ ДИСПЛАЗИЕЙ. ЦЕЛЬЮ работЫ бЫЛО изУчИть Заболеваемость и развИтИе недоношенных детей с бронхолегочной дисплазией (БЛД) в течение первых двух лет жизни и идентифицировать факторы риска, включая полиморфизм G3T генов, которые достоверно ассоциируются с развитием негативных исходов при БЛД. Проведено когортное проспективное исследование, в которое включили 33 ребенка с БЛД, выписанных из лечебных учреждений Полтавской области в течение 2010-2013 гг. Изучены их психоэмоциональное, статокинетическое развитие в 6, 12, 18 и 24 месяца жизни. Оценена частота острых респираторных вирусных инфекций, бронхита и пневмонии в те же возрастные периоды. Исследована частота выявления полиморфизма GSTT1, GSTM1 u GSTP1 генов. Для изучения связи между определенными независимыми переменными и клинико-генетическими факторами проведен логистический регрессионный анализ. Делеционный полиморфизм генов семейства глутатион3-трансфераз не связан со статокинетическим и психоэмоциональным развитием детей с БЛД, а также с повышенной частотой у них острых инфекционных заболеваний органов дыхания в течение первых двух лет жизни. Психоэмоциональное развитие детей с БЛД достоверно ассоциируется с длительностью ИВЛ (ОШ 1,269; 95 \% ДИ $1,01-1,603, p=0,045)$ и не ассоциируется с другими факторами (масса при рождении, гестационный возраст, обеспечение калориями и белком на 28 сутки жизни, мужской пол). Не выявлено существенного влияния генетических факторов на развитие недоношенных детей с БЛД и их заболеваемость острыми инфекционными заболеваниями органов дыхания. Требуются дальнейшие исследования на большем количестве пациентов для поиска клиникогенетических факторов, влияющих на негативные отдаленные исходы у детей с Блд.

EFFECT OF GENE POLYMORPHI3M FAMILY GLUTATHIONE-3-TRAN3FERA3E3 IN THE DEVELOPMENT AND MORBIDITY OF PREMATURE INFANT3 WITH BRONCHOPULMONARY DY3PLA3IA. The purpose of the present paper was to study the morbidity and development of premature infants with BPD in the first two years of life and to identify risk factors including G3T genespolymorphisms that are significantly associated with the negative outcomes of BPD. A cohort prospective study included 33 children with BPD who were discharged from Poltava children hospitals during 2010-2013. Their psychoemotional and statokinetic development in $6,12,18$ and 24 months of life were studied. Incidence of acute respiratory viral infections, bronchitis and pneumonia in the same ages was reviewed. The rate of detection of polymorphism G3TT1, G3TM1 and G3TR1 genes was studied. Multiple logistic regression analysis was conducted in order to study the relationship between certain independent variables, clinical and genetic factors. Deletion of glutathione-3-transferas polymorphism is not associated with statokinetic and psychoemotional development of children with BPD and with increased rate of acute infectious respiratory diseases during the first two years of life. Psychoemotional development of childrenwith BPD was significantly associated with the duration of mechanical ventilation (OR $1.269 ; 95 \% \mathrm{Cl} 1.01-1.603$, $\mathrm{p}=0.045$ ) and not associated with other factors (birth weight, gestational age, providing calories after 28 days of life, providing protein at 28 days of life, male). There was no significant effect of clinical and genetic factors on the development of premature infants with BPD and rate of acute infectious respiratory diseases. Further studies on larger cohort of patients are needed to find clinical and genetic factors that influence on adverse developmental and clinical outcomes in children with BPD.

Ключові слова: бронхолегенева дисплазія, психоемоційний розвиток, захворюваність, GSTT1, GSTM1, GSTP1 гени.

Ключевые слова: бронхолегочная дисплазия, психоэмоциональное развитие, заболеваемость, GSTT1, GSTM1, GSTP1 гены.

Key words: bronchopulmonary dysplasia, psychoemotional development, morbidity, GSTT1, GSTM1, GSTR1 genes. 


\section{Педіатрія}

ВСТУП. Бронхолегенева дисплазія (БЛД) залишається однією із серйозних проблем передчасно народжених дітей, особливо тих, які народились 3 екстремально низькою масою тіла $[1,2]$. На сьогодні патогенез захворювання залишається складним та не повністю зрозумілим. Але відомо декілька факторів, роль яких у патогенезі $є$ доведеною. Зокрема, це передчасні пологи, легенева баротравма/волюмтравма, гіпероксія і запалення [3, 4]. Водночас залишаються дискусійними питання щодо генетичної детермінанти розвитку захворювання. Відомо, що глутатіон-Б-трансферази (GST фрерменти), особливо рі, ти i theta підкласи, є відповідальними за зниження продуктів окиснення ліпідів у легенях і за модуляцію синтезу ейкозаноїдів та інших запальних медіаторів [5]. Тому зміни в активності GST ферментів можуть мати істотний вплив на відповідь окремої дитини на запалення і окиснювальний стрес далеко за межами простого зменшення кисневих радикалів. Наші попередні роботи довели внесок поліморфізму генів сімейства глутатіон-Б-трансфераз у розвиток БЛД [6]. Так, виявлено достовірні асоціації між делеційним поліморфізмом GSTM1 гена та розвитком БЛД, між делеційним поліморфізмом GSTT1 гена та тривалістю ШВЛ, між однонуклеотидною заміною GSTP1 гена в гомозиготному або гетерозиготному стані та розвитком пізніх інфекцій (після 7 доби життя дитини). Ми припустили, що поліморфізм зазначених генів може впливати на статокінетичний, психоемоційний розвиток дітей з БЛд та підвищувати частоту гострих інфекційних захворювань органів дихання. Тому метою дослідження було вивчити захворюваність i розвиток передчасно народжених дітей з БЛД упродовж перших двох років життя та ідентифікувати фактори ризику, включаючи поліморфізм GST генів, які достовірно асоціюються 3 негативними наслідками при БЛД.

МАТЕРІАЛИ ТА МЕТОДИ. У дослідження вкЛючено 49 немовлят, які виписані 3 лікувальних закладів Полтавської області з діагнозом БлД упродовж 2010-2013 рр. 3 включених у дослідження дітей 16 було виключено з таких причин: вибуття за межі області (n=7), нерегулярне спостереження у центрі розвитку дитини Полтавської обласної дитячої клінічної лікарні (п=8), летальний випадок $(n=1)$. Таким чином, у групу дослідження ввійшло 33 дитини, в яких упродовж двох років оцінювали статокінетичний, психоемоційний розвиток у $6,12,18$ та 24 місяці як хронологічного, так і скорегованого віку та моніторили їх захворюваність на гострі інфекційні захворювання верхніх дихальних шляхів. Батьки дали згоду на участь їх дітей у дослідженні.

Досліджували такі негативні наслідки: затримку психоемоційного розвитку у 12 місяців корегованого віку та підвищену захворюваність на гострі інфекційні захворювання органів дихання. Затримку психоемоційного розвитку виставляли при невідповідності розвитку дитини критеріям, викладеним у додатку № 4 «Оцінка психомоторного розвитку дитини раннього віку» наказу МОЗ України № 149 від 20.03.2008 р. «Клінічний протокол медичного догляду за здоровою дитиною віком до 3 років» [7]. Підви- щену частоту гострих інфекційних захворювань органів дихання визначали при наявності у дитини таких критеріїв: а) більше 2 епізодів на півріччя гострих респіраторних вірусних інфекцій (ГРВІ); б) 1 епізод на півріччя гострого або обструктивного бронхіту; в) 1 епізод на півріччя пневмонії.

Аналіз делеційного поліморфізму GSTT1, GSTM1 генів проводили 3 використанням мультиплексної полімеразної ланцюгової реакції. Для визначення поліморфних варіантів A313G 5 екзону GSTP1 гена також виконували полімеразну ланцюгову реакцію 3 подальшим рестрикційним аналізом продуктів реакції ампліфікації. Детекцію продуктів полімеразної ланцюгової реакції та рестрикційного аналізу проводили в агарозному гелі. Ампліфікацію виділеної ДНК здійснювали в реакційній суміші за M. Arand [8]. Ампліфіковані фрагменти розподіляли з використанням горизонтального електрофорезу в 1,5 \% агарозному гелі із забарвленням бромистим етидієм.

Проаналізовано 6 кандидатів прогностичних змінних, можливо, пов'язаних із затримкою нервово-психічного розвитку (маса при народженні, гестаційний вік, забезпечення калоріями і білком на 28 добу життя, тривалість ШВЛ та чоловіча стать), і 10 кандидатів прогностичних змінних, можливо, пов'язаних із підвищеною захворюваністю на гострі інфекційні захворювання органів дихання у передчасно народжених дітей з БЛД (маса при народженні, гестаційний вік, забезпечення калоріями і білком на 28 добу життя, тривалість ШВЛ, чоловіча стать, пізні інфекції, куріння батьків, розміщення житла ближче ніж 100 м до автотраси та проживання в місті). За допомогою простого логістичного регресійного аналізу розрахували шанси дитини з БЛД мати негативні наслідки при наявності у неї поліморфізму GST генів, а за допомогою множинного логістичного регресійного аналізу - шанси дитини з БЛД мати негативні наслідки при наявності у неї вищенаведених клінічних факторів ризику. Статистичний аналіз проводили з використанням програми STATA версії 11 для Windows (StataCorp, Texac, США). Відношення шансів (ВШ) з $95 \%$ довірчими інтервалами (ДІ) були використані для ідентифікації факторів ризику. Порівняння відносних або виражених у відсотках величин здійснювали за допомогою критерію $\mathrm{x}^{2}$ (xiквадрат). Значення $p<0,05$ вважали статистично значущими.

РЕЗУЛЬТАТИ ДОСЛІДЖЕННЯ ТАЇХ ОБГОВОРЕННЯ. Вивчення статокінетичного розвитку показало, що у 6 місяців хронологічного віку всі діти з БлД мали його затримку, але при оцінюванні статокінетичного розвитку відповідно до скорегованого віку відставання виявили лише у 29,17 \% дітей (рис. 1).

До 12 місяців як хронологічного, так і скорегованого віку частки дітей із затримкою статокінетичного розвитку залишалися незмінними. Наприкінці 2 років хронологічного віку, порівняно з 6 місяцями, частка таких дітей достовірно зменшилась і становила $27,0 \%(p<0,001)$. Проте при оцінюванні статокінетичного розвитку відповідно до скорегованого віку частки дітей з його затримкою залишились майже незмінними $(p=0,16)$. Затримку психоемоційного роз- 


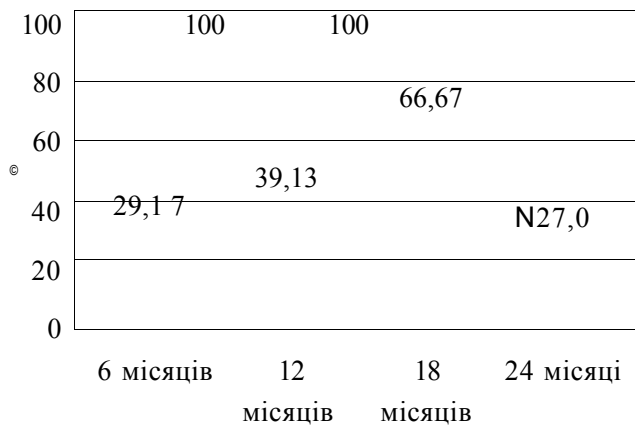

• Хронологічний вік -•- Скорегований вік

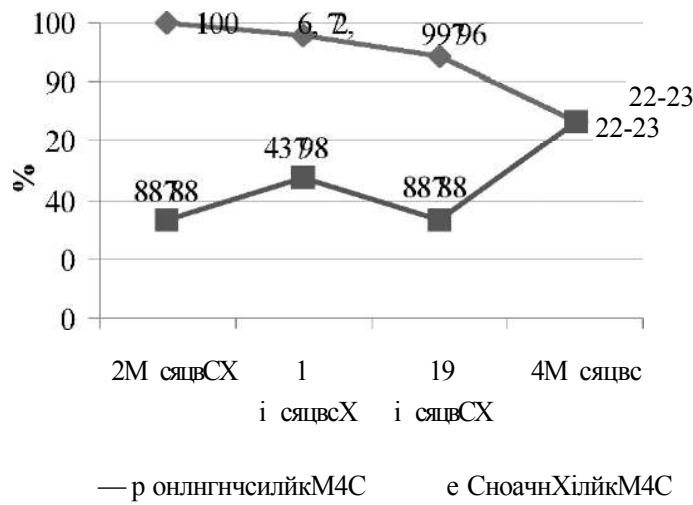

Психоемоційний розвиток

Рис. 1. Кількість дітей з відставанням розвитку в різні вікові періоди.

витку в 6 місяців хронологічного віку мали всі діти з БЛД, а в 6 місяців скорегованого віку - лише 33,3 \% дітей. Слід відмітити, що у 24 місяці як хронологічного, так і скорегованого віку 66,7 \% дітей продовжували мати затримку психоемоційного розвитку. Наведені дані свідчать про значну кількість передчасно народжених дітей з БЛД, які мали відставання статокінетичного та психоемоційного розвитку. При цьому в 2 роки як хронологічного, так і скорегованого віку їх кількість стала майже однаковою. Тому розвиток передчасно народжених дітей із БЛД доцільно оцінювати відповідно до скорегованого віку.

Зважаючи на отримані дані, проаналізовано зв'язок між затримкою окремих видів розвитку в передчасно народжених дітей з БЛД та поліморфізмом генів сімейства глутатіон-Б-трансфераз (табл. 1). Простий логістичний регресійний аналіз довів відсутність асоціацій між поліморфізмом GST генів та порушенням статокінетичного і психоемоційного розвитку в дітей з БЛД.

Як було вказано вище, найбільша частка дітей у 12 місяців скорегованого віку мала затримку психоемоційного розвитку. Тому саме цей критерій був обраний незалежною змінною для з'ясування та ідентифікації факторів, які найбільше впливають на його затримку (табл. 2). Множинний логістичний регресійний аналіз довів наявність достовірних асоціацій між тривалістю ШВЛ та затримкою психоемоційного розвитку в дітей 3 БЛД у 12 місяців скорегованого віку (ВШ 1,269; $95 \%$ ДІ 1,01-1,603, p=0,045). Наші попередні роботи довели достовірний вплив поліморфізму GSTT1 та GSTP1 генів на тривалість ШВЛ [9], тому ми припускаємо, що діти з таким поліморфізмом мають генетичну сприйнятливість до тривалої ШВЛ, яка, у свою чергу, в подальшому впливає на їх психоемоційний розвиток.

На нашу думку, одержані дані можуть слугувати підґрунтям для запровадження генетичного дослідження на визначення поліморфізму GST генів удітей з тривалою ШВЛ (на 14 добу життя) 3 метою віднесення їх до групи ризику щодо розвитку БлД та затримки психоемоційного розвитку.

Слід відмітити, що у нашому дослідженні ні маса дитини, ні її гестаційний вік не впливають на подальший розвиток дитини. Напевно, є інші фактори, які пов'язані із затримкою психоемоційного розвитку і які потребують подальшого дослідження.

Таблиця 1. Асоціації між затримкою окремих видів розвитку в дітей 12-місячного скорегованого віку та поліморфізмом GST генів (ВШ; 95 \% ДI)

\begin{tabular}{|c|c|c|c|c|c|c|}
\hline Незалежна змінна & GSTT1 & $P$ & GSTM1 & $\mathrm{P}$ & $\begin{array}{l}\text { GSTP1 } \\
A G+G G\end{array}$ & $P$ \\
\hline $\begin{array}{l}\text { Порушення статокінетичного } \\
\text { розвитку (так/ні) }\end{array}$ & $\begin{array}{c}0,8 \\
0,06-11,29\end{array}$ & 0,869 & $\begin{array}{c}0,371 \\
0,06-2,30\end{array}$ & 0,313 & $\begin{array}{c}2,0 \\
0,50-7,99\end{array}$ & 0,608 \\
\hline $\begin{array}{l}\text { Порушення психоемоційного } \\
\text { розвитку (так/ні) }\end{array}$ & $\begin{array}{c}0,65 \\
0,21-1,97\end{array}$ & 0,61 & $\begin{array}{c}0,5 \\
0,08-0,99\end{array}$ & 0,584 & $\begin{array}{c}0,75 \\
0,24-2,32\end{array}$ & 0,500 \\
\hline
\end{tabular}

Таблиця 2. Зв'язок між затримкою психоемоційного розвитку в дітей 12-місячного скорегованого віку та окремими клінічними факторами за множинним логістичним регресійним аналізом (ВШ; $95 \%$ ДI)

\begin{tabular}{|l|c|c|c|}
\hline \multicolumn{1}{|c|}{ Залежна змінна } & ВШ & $95 \%$ ДI & P \\
\hline Маса при народженні (г) & 1,00 & $0,99-1,010$ & 0,708 \\
\hline Гестаційний вік (тижні) & 0,6430 & $0,18-2,188$ & 0,480 \\
\hline Забезпечення калоріями на 28 добу життя (ккал/кг) & 0,99 & $0,88-1,114$ & 0,941 \\
\hline Забезпечення білком на 28 добу життя (г/кг) & 19,55 & $0,25-1525,4$ & 0,181 \\
\hline Тривалість ШВЛ (доби) & 1,2694 & $1,01-1,603$ & 0,045 \\
\hline Чоловіча стать (так/ні) & 0,27 & $0,009-8,18$ & 0,459 \\
\hline
\end{tabular}




\section{Педіатрія}

Вивчення в дітей з БлД частоти гострих інфекційних захворювань органів дихання показало, що у третини з них у середньому за перші два півріччя спостерігалось по 2 епізоди ГРВІ (рис. 2).

Після 18 місяців життя кількість дітей, у яких відмічено три та більше епізодів ГРВІ, збільшилась 3 5,3 до $33,3 \%, p=0,060$. Частота гострого бронхіту, обструктивного синдрому та пневмонії в дітей з Блд у різні вікові періоди була майже однаковою. Дослідження впливу поліморфізму генів сімейства глутатіон-Б-трансфераз на підвищену частоту гострих інфекційних захворювань органів дихання у перед-

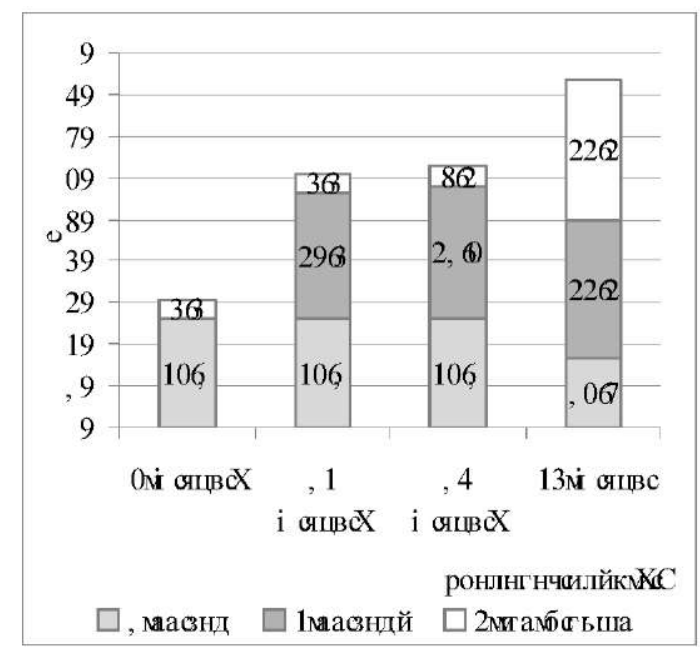

ГPBI

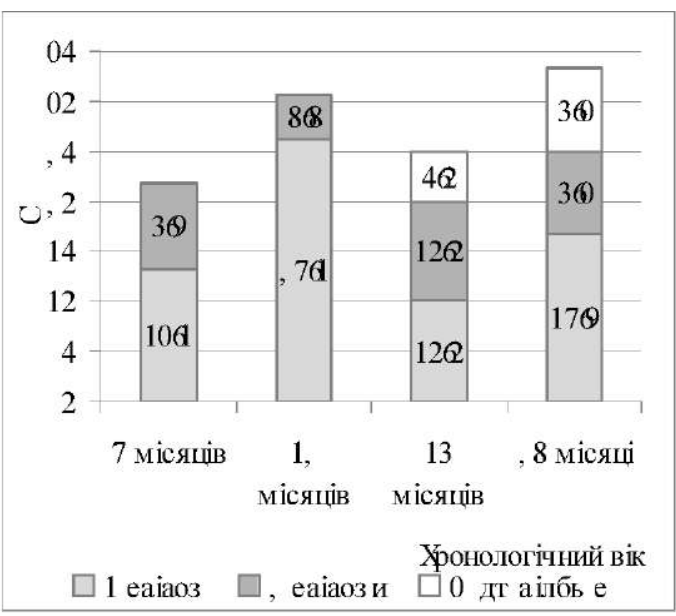

Обструктивний бронхіт часно народжених дітей з БЛД довело відсутність достовірних асоціацій між делеційним поліморфізмом GSTT1, GSTM1 генів, однонуклеотидною заміною в гетеро- та гомозиготному стані GSTP1 гена та частими захворюваннями органів дихання (табл. 3).

Результати, наведені в таблиці 4, вказують на відсутність достовірного зв'язку між гострими інфекційними захворюваннями органів дихання у дітей з БЛД та низкою медико-соціальних факторів. Це свідчить про наявність інших причин, які достовірно впливають на частоту гострих захворювань органів дихання в дітей з БЛД і які потребують подальшого вивчення.

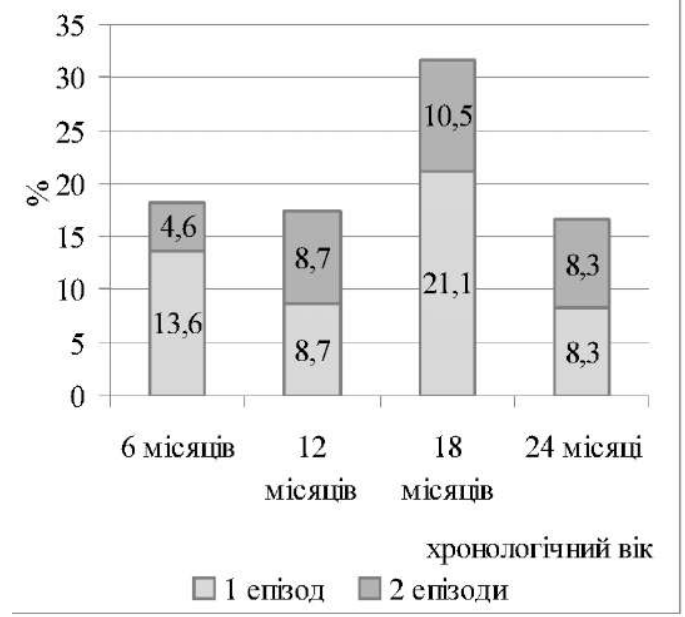

Гострий бронхіт

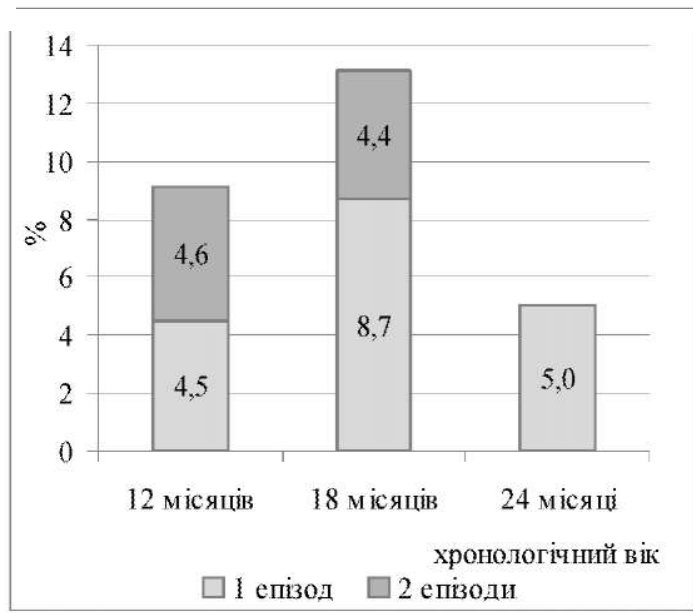

Пневмонія

Рис. 2. Частки дітей, які мали гострі інфекційні захворювання органів дихання, у різні вікові періоди.

Таблиця 3. Асоціації між підвищеною частотою захворювань органів дихання у передчасно народжених дітей 3 Блд упродовж перших двох років життя та поліморфізмом GST генів (ВШ; 95 \% ДI)

\begin{tabular}{|l|c|c|c|c|c|c|}
\hline \multicolumn{1}{|c|}{ Незалежна змінна } & GSTT1 & $\mathrm{P}$ & GSTM1 & $\mathrm{P}$ & $\begin{array}{c}\text { GSTP1 } \\
A G+G G\end{array}$ & $\mathrm{P}$ \\
\hline Часті ГРВІ (так/ні) & $\begin{array}{c}2,5 \\
0,15-42,80\end{array}$ & 0,527 & $\begin{array}{c}10,0 \\
0,58-171,20\end{array}$ & 0,11 & $\begin{array}{c}2,8 \\
0,19-40,05\end{array}$ & 0,448 \\
\hline $\begin{array}{l}\text { Обструктивний бронхіт } \\
\text { (так/ні) }\end{array}$ & $\begin{array}{c}1,0 \\
0,06-14,64\end{array}$ & 1,000 & $\begin{array}{c}2,66 \\
0,25-28,43\end{array}$ & 0,41 & $\begin{array}{c}0,666 \\
0,07-5,87\end{array}$ & 0,715 \\
\hline
\end{tabular}




\section{Педіатрія}

Таблиця 4. Зв'язок між частими гострими інфекційними захворюваннями органів дихання у дітей та окремими медико-соціальними факторами за множинним логістичним регресійним аналізом (ВШ; $95 \%$ ДI)

\begin{tabular}{|l|c|c|}
\hline \multicolumn{1}{|c|}{ Залежна змінна } & ВШ & P5 \% ДI \\
\hline Маса при народженні (г) & 1,0091 & $0,99-1,027$ \\
\hline Гестаційний вік (тижні) & 0,110 & $0,003-3,151$ \\
\hline Забезпечення калоріями на 28 добу життя (ккал/кг) & 1,02 & $0,87-1,190$ \\
\hline Тривалість ШВЛ (доби) & 1,144 & $0,87-1,49$ \\
\hline Стать чоловіча (так/ні) & 0,7 & 0,197 \\
\hline Пізні інфекції (так/ні) & 3,07 & 0,794 \\
\hline Куріння батьків (так/ні) & 0,35 & $0,377-124,5$ \\
\hline Проживання ближче ніж 100 м до автотраси (так/ні) & 0,36 & $0,0589-2,16$ \\
\hline Проживання в місті (так/ні) & 0,83 & $0,065-3,14$ \\
\hline
\end{tabular}

Результати наших досліджень засвідчили, що діти з БЛД часто мають затримку статокінетичного, психоемоційного розвитку та підвищену частоту гострих інфекційних захворювань органів дихання. Такі результати дослідження одержали й інші автори [10]. На думку вчених, до цього призводять тривала киснева та респіраторна терапія [1], часте застосування глюкокортикостероїдів та епізоди гіпоксемії [2]. Наші дані свідчать, що саме тривала ШВЛ збільшує шанси дитини мати затримку психоемоційного розвитку.

У науковій літературі $€$ дані про наявність зв'язків між поліморфізмом генів сімейства глутатіон-S-трансфераз та підвищеною частотою пневмонії, респіраторних інфекцій, перинатальної патології [11, 12], хронічних обструктивних захворювань легень та бронхіальної астми [13, 14]. Але наші дослідження не довели достовірного впливу поліморфізму генів сімейства глутатіон ${ }^{\wedge}$-трансфераз на розвиток дітей та їх підвищену захворюваність упродовж перших двох років життя. Ми звертаємо увагу на малу вибірку пацієнтів, які були включені в дослідження, і відсутність статистичної значущості отриманих результатів. Проте вважаємо, що наші результати потребують уваги та подальшого дослідження на більшій кількості передчасно народжених дітей з Блд.

\section{СПИСОК ЛІТЕРАТУРИ}

1. Outcomes of extremely low birth weight infants with bronchopulmonary dysplasia: impact of the physiologic definition / G. Natarajan, A. Pappas, S. Shankaran [et al.] // Early Hum. Dev. - 2012. - Vol. 88, №7. P. 509-515.

2. Bronchopulmonary dysplasia predicts adverse developmental and clinical outcomes in very-lowbirthweight infants / S. F. Jeng, C. H. Hsu, P. N. Tsao [et al.] // Dev. Med. Child. Neurol. - 2008. - Vol. 50, №1. - P. 51-57.

3. Woynarowska M. Risk factors, frequency and severity of bronchopulmonary dysplasia (BPD) diagnosed according to the new disease definition in preterm neonates / M. Woynarowska, M. Rutkowska, K. Szamotulska //Med. Wieku Rozwoj. - 2008. Vol. 12. - P. 933-941.

4. Асоціації між бронхолегеневою дисплазією та позитивною культурою крові у передчасно народжених дітей упродовж неонатального періоду / Кова-
ВисновкИ. 1. Діти з БЛД у 24 місяці корегованого віку мають затримку статокінетичного розвитку в $9,1 \%$ випадків та затримку психоемоційного розвитку в $66,7 \%$ випадків.

2. Психоемоційний розвиток дітей з Блд достовірно асоціюється з тривалістю ШВЛ (ВШ 1,269; $95 \%$ ДI $1,01-1,603, p=0,045)$ та не асоціюється 3 іншими факторами (маса при народженні, гестаційний вік, забезпечення калоріями та білком на 28 добу життя, чоловіча стать).

3. Делеційний поліморфізм генів сімейства глутаті$\mathrm{oн}^{\wedge}$-трансфераз не пов'язаний зі статокінетичним та психоемоційним розвитком дітей з БЛД, а також з підвищеною частотою гострих інфекційних захворювань органів дихання упродовж перших двох років життя.

ПЕРСПЕКТИВИ ПОДАЛЬШИХ ДОСЛІДЖЕНЬ. ПОдальші дослідження будуть спрямовані на: а) виявлення специфічних генів-кандидатів, які беруть участь у патофізіологічних механізмах розвитку БЛД та її негативних наслідках; б) доповнення нашого розуміння щодо ролі поліморфізму генів сімейства глутатіонS-трансфераз у розвитку респіраторної патології, що буде здійснено на більшій кількості дітей; в) розробку нових підходів до оцінки ризику розвитку патологічних станів у передчасно народжених дітей з БЛД та індивідуалізованого підходу до їх лікування.

льова О. М., Горовенко Н. Г., Чернявська Ю. І., Гончарова Ю. О. // Актуальні проблеми сучасної медицини. - 2014. - Т.14, № 1 (45). - С. 68-71.

5 Hayes J. D. Glutathione-S-transferase polymorphisms and their biological consequences / J. D. Hayes, R. C. Strange // Pharmacology. - 2000. Vol. 61. - P. 154-166.

6. Оценка влияния факторов риска полиморфизма GST-генов на развитие бронхолегочной дисплазии у преждевременно рожденных детей / Ковалева Е. М., Горовенко Н. Г., Похилько В. И. [и др.] // GMN: Медицинские грузинские новости. - 2014. № 9 (234). - С. 105-112.

7. Клінічний протокол медичного догляду за здоровою дитиною віком до 3 років : наказ МОЗ України № 149 від 20.03.2008 р. // Офіційний вісник України. - 2008. -67 c

8. A Multiplex Polymerase Chain Reaction Protocol for the Simultaneous Analysis of the Glutathione S- 


\section{Педіатрія}

Transferase G3TM1 and G3TT1 Polymorphisms / M. Arand, R. Muhlbauer, J. Hengstler [et al.] // Analytical Biochemistry. - 1996. - № 236. - P.184-186.

9. Ковальова О. М. Дослідження асоціації' поліморфрізму генів сімейства глутатіон-3-трансфераз: G3TM1, G3TT1, G3TP1 з розвитком бронхолегеневої дисплазії та потребою в респіраторній підтримці / О. М. Ковальова, В.І.Похилько, Ю. О. Гончарова // Неонатологія, хірургія та перинатальна медицина. - 2014. - Т. 4, № 2 (12). - C. 50-57.

10. Bhandari A. Pulmonary outcomes in bronchopulmonary dysplasia / A. Bhandari, H. B. Panitch $/ \wedge$ emin. Perinatol. - 2006. - Vol. 30. - P. 219-226.

11. Wu Weidong. Role of G3TM1 in Resistance to Lung Inflammation / Weidong Wu, David Peden, David Diaz- 3anchez // Free Radic. Biol. Med. -2012. -Vol. 53, №4. - P. 721-729.

12. Визначення генетичної' детермінанти у розвитку перинатальної асфіксії новонароджених / Н. Г. Горовенко, Т. К. Знаменська, В.І. Похилько [та ін.] // Перинатология и педиатрия. - 2009. № 4 (40). - C. 37-40.

13. 3aadat M. Genetic polymorphism of glutathione 3-transferase T1, M1 and asthma, a meta-analysis of the literature / M. 3aadat, M. Ansari-Lari // Pak. J. Biol. 3a.2007. - Vol. 10, № 23. - P. 4183-4189.

14. Glutathiones-transferase G3TP1, G3TM1, exercise, ozone and asthma incidence in school children / T. Islam, K. Berhane, R. McConnell [et al.] // Thorax.2009. - Vol. 64, № 3. - P. 197-202. 